\author{
논에서 생산된 옥수수의 수확시기가 곤포사일리지의 사료가치와 \\ 품질에 미치는 영향 \\ 최기춘 ${ }^{1} \cdot$ 조남철 $^{1} \cdot$ 정민웅 $^{1} \cdot$ 이경동 $^{2} \cdot$ 김종근 $^{1} \cdot$ 임영철 $^{1} \cdot$ 김원호 $^{1} \cdot$ 오영균 $^{1} \cdot$ 최진혁 $^{1} \cdot$ \\ 김천만 $^{1} \cdot$ 정두근 $^{1} \cdot$ 최종만 $^{1}$
}

\title{
Effect of Harvest Stage of Corn on Nutritive Values and Quality of Roll Baled Corn Silage Manufactured with Corn Grown in Paddy Land
}

Ki Choon Choi ${ }^{1}$, Nam Chul Jo', Min-Woong Jung ${ }^{1}$, Kyung Dong Lee ${ }^{2}$, Jong Geun Kim', Young Chul Lim', Won Ho Kim¹, Yung Keun $\mathrm{Oh}^{1}$, Jin Hyuk Choi ${ }^{1}$, Cheon Man Kim¹, Du Keun Jung ${ }^{1}$ and Jong Man Choi ${ }^{1}$

\begin{abstract}
This study was carried out to examine the effect of harvest stage of corn on nutritive values and quality of round baled corn silage manufactured with corn grown in paddy land of Department of Animal Resources Development, National Institute of Animal Science, RDA from 2009 to 2010. Corn "Kwangpyungok" was harvested at three different growth times (milk, yellow ripen and ripen stage) and ensiled at each harvest stages. Crude protein (CP) and TDN (total digestible nutrient) contents of round baled corn silage was decreased and in vitro dry matter digestibility (IVDMD) was not changed with delayed harvest maturity. However, contents of $\mathrm{ADF}$ (acid detergent fiber) and NDF(neutral detergent fiber) decreased with delayed harvest maturity. The $\mathrm{pH}$ at three different harvest stages ranged from 3.8 to 4.0. The content of lactic acid increased with delayed harvest maturity, but the content of acetic acid decreased. And then, flieg's score reveals that there is an increase in order, ripen stage $>$ yellow ripen stage $>$ milk stage. Therefore, this study suggest that round baled corn silage manufactured at yellow ripen stage can improve the silage quality.
\end{abstract}

(Key words : Corn, Silage, Round bale, Quality, Organic acid)

I. 서 론 부, 2010), 최근 수입조사료와 곡물가격의 급등

우리나라 일부 양축농가는 조사료에 대한 인 식 부족으로 매년 막대한 양의 조사료를 수입 (2009년 830천톤)에 의존하고 있는데 (농림수산
으로 인하여 자급 양질 조사료 생산과 이용측 면에서 많은 관심을 갖기 시작했다. 특히, 높은 곡물가격으로 인하여 소 사육농가의 부담이 크 게 증가됨에 따라 양질 조사료의 생산과 이용

\footnotetext{
${ }^{1}$ 농촌진흥청 국립축산과학원 (National Institute of Animal Science, RDA, Cheonan 331-808, Korea)

2 동신대학교 (Dongsin University, Naju, 520-714, Korea)

Corresponding author: Ki Choon Choi, National Institute of Animal Science, RDA, Cheonan 331-808, Korea.

Tel: +82-41-580-6755, Fax: +82-41-580-6779, E-mail: choiwh@korea.kr
} 
에 관한 기술개발에 양축농가와 축산관련기관 등에서 많은 관심이 이루어지고 있다. 한편, 농 산물 시장의 개방과 식품소비 경향의 변화로 벼 재배 면적 감소추세와 수입쌀의 증가로 인 한 쌀 재고량 증가는 유휴논의 발생을 증가시 켜 농업의 많은 문제점을 일으키고 있으나(서 와 이, 2009; 송 등, 2007 ; 이 2006; 이 등 2006; 전, 2004) 축산관련 산 · 학 - 연 - 정 등은 유휴 논에 사료작물을 재배하여 양질 조사료를 생산하면 다량의 수입조사료를 대체하는 효과 와 더불어 조사료 자급율을 향상시킬 수 있는 기회로 만들고자 많은 노력을 기울이고 있는 실정이다 (김 등, 2010; 김 등, 2009; 신 등, 2008; 조, 2007; 김 등 2005). 이러한 일환으로 답작지에서 습해에 강하고 생산성이 우수한 벼 대체 하계사료작물인 옥수수를 재배하여 양질 의 옥수수 사일리지를 공급하고자 하는 노력이 진행되고 있다 (지 등, 2009a; 지 등, 2009b).

이제까지 옥수수 사일리지 제조는 트렌치 방 법이나 AG-bag 등이 널리 이용(성 등, 2005)되 고 있기 때문에 이들 방법은 유통사료화에 적 합하지 않아 유통사료로서 기능을 갖는 조제방 법기술 개발이 필요하여 일부에서는 원형곤포 기나 톤백 등 제조방법을 다양하게 시도하고 있으나 효과를 거두지 못하고 있는 실정이다.

총체보리, 호밀, 이탈리안 라이그라스, 볏짚 등 줄기가 연한 사료작물은 현재 보급이 일반 화 되어있는 원형곤포기로 곤포조제가 가능하 나(김 등, 2010; 김 등, 2006a; 김 등, 2006b; 김 등, 2004 ; 김 등, 2001 ; 김 등, $2000 \mathrm{a}$; 김 등, $2000 \mathrm{~b}$; 김 등, 1995 ; Bevre, 1988; Romahn, 1988), 줄기가 굵고 단단한 옥수수나 수수류는 현재 보급중인 곤포기로는 조제가 어렵기 때문 에 옥수수 전용 원형곤포기가 필요하여 많은 종류가 개발되고 있으며 일부는 보급 중에 있 다.

곤포 사일리지는 절단분쇄에 의한 관행적 사 일리지 조제 방법에 비해 운반 및 저장 등에 소요되는 노동력을 현저하게 절감시킬 수 있는
장점이 있는 것으로 보고되고 있다. 그러나 일 반적으로 유통되고 있는 곤포사일리지는 사일 리지 제조자가 제조 적기에 사일리지를 제조하 는 것이 아니라 일손과 기후여건에 따라 제조 하는 경우가 많아 적기보다 일찍 또는 늦게 조제하기 때문에 사일리지의 수분함량이 차이 가 많고, 특히 수분이 과다할 경우 사일리지의 품질에 나쁜 영향을 미치므로 정부에서는 사일 리지 품질에 따라 차등을 두어 보조금을 지급 하고 있다 (농림수산부, 2010).

따라서 본 연구에서는 옥수수의 수확시기에 따라 현재보급중인 원형 곤포사일리지 제조기 를 이용하여 사일리지를 조제하였을 때 옥수수 의 사일리지 사료가치 및 유기산 등 품질 변화 를 조사하여 품질이 우수한 옥수수 곤포사일리 지 제조를 위한 기초자료를 얻기 위해서 수행 하였다.

\section{П. 재료 및 방법}

\section{1. 포장시험 및 사일리지 제조}

본 시험은 2009년부터 2010년까지 충남 천안 답리작에서 2년간 수행되었다. 공시초종으로 옥수수(광평옥)를 4월 중순에 파종하였는데 옥 수수의 파종은 트랙터에 부착된 옥수수 파종기 로 파종하였고, 시비는 옥수수 표준시용량으로 $200-150-150 \mathrm{~kg} / \mathrm{ha}\left(\mathrm{N}-\mathrm{P}_{2} \mathrm{O}_{5}-\mathrm{K}_{2} \mathrm{O}\right)$ 를 시비하였다. 이 중 질소는 기비로 $50 \%$, 추비로 $50 \%$ 시용하였 으며 인산과 칼리는 전량기비로 시용하였다.

수확은 옥수수는 유숙기 (8월 초순), 황숙기 (8월중순), 완숙기 (8월말), 즉 황숙기 기준으로 유숙기는 10 일전, 완숙기는 10 일후에 수확하였 다.

사일리지 조제는 수확시기별로 옥수수 수확 기 (Kemper C $3000 \mathrm{H}, \mathrm{KemPer}$, 독일)를 이용하 여 수확 (절단길이 2 3 cm) 하였으며 옥수수 젖 산균 첨가제 (청미바이오, 한국)를 처리하여 각 처리당 3 롤의 원형 곤포사일리지를 조제하였다. 
원형 곤포사일리지 조제는 옥수수 전용 원형 곤포기 (Bio325, $\mathrm{ViCon}$, 독일)를 이용하여 지름 $120 \mathrm{~cm}$, 높이 $120 \mathrm{~cm}$ 규격의 대형 원형곤포를 만들었고 곤포제조와 동시에 분무기로 젖산균 첨가제를 권장량 골고루 살포한 다음 Wrapper (Bio325, ViCon, 독일)를 이용하여 16 18겹의 비닐을 감아 제조하였다. 사일리지 wrapping에 쓰인 비닐은 두께가 $25 \mu \mathrm{m}$ 이고 폭은 $800 \mathrm{~mm}$ 이 며 길이는 $1,800 \mathrm{~m}$ 인 백색 비닐이었다.

대조구의 옥수수 사일리지는 매 수확시기마 다 $20 \ell$ 플라스틱 시험용 사일로에 충진 시킨 후 완전 밀봉 (트렌치)하여 그늘에서 보관한 다 음 원형 곤포사일리지와 함께 약 60 일을 보관 한 후 개봉하여 사료가치 등을 조사하였다.

\section{2. 사료가치 분석}

옥수수 사일리지의 사료가치를 조사하기 위 하여 각 시험구에서 저장 60 일 후 사일리지 시 료채취기 (Uni-Forage Sampler; STAR QUALITY SAMPLER Co. Canada)로 각 처리구당 약 $500 \mathrm{~g}$ 을 취하여 일부는 $65^{\circ} \mathrm{C}$ 순환식 송풍건조기에서 3 일간 건조 후 분쇄하여 시료의 Crude protein (CP)은 A.O.A.C. 법 (1990)에 의해 분석하였고, Neutral detergent fiber(NDF) 및 Acid detergent fiber (ADF) 함량은 Goering 및 Van soest법 (1970)으로 분석하였다. In vitro 건물소화율은 Moore (1970)의 방법을 이용하였으며, TDN 함 량은 Jurgens (1988) 방법을 수정하여 계산하였 다. 그리고 나머지 일부는 $-20^{\circ} \mathrm{C}$ 냉동고에 보 관하였다가 사일리지 특성 조사에 사용하였다.

사일리지의 $\mathrm{pH}$ 와 유기산 성분은 개봉한 사 일리지 $10 \mathrm{~g}$ 을 증류수 $100 \mathrm{ml}$ 에 넣고 $4^{\circ} \mathrm{C}$ 에서 24 시간 진탕 후 4중 거즈 (Gauze)로 1차 거른 뒤 여과지(Whatman No. 6)를 통하여 걸러서 추출액을 조제하여 $\mathrm{pH}$ 는 $\mathrm{pH}$ meter (HI 9024; HANNA Instrument Inc. UK)로, 그리고 젖산은 $0.22 \mu \mathrm{m}$ 실린지 필터를 사용하여 여과시킨 다음 HPLC (HP1100. Agilent Co. USA)로 분석하였
다. 초산과 낙산 분석은 Gas chromatography (GC-450, Varian Co., USA)를 이용하여 분석하 였다. 추출액은 분석에 이용할 때까지 $-70^{\circ} \mathrm{C}$ 에서 냉동보관 하였다.

본 시험에서 얻은 모든 결과는 Windows용 SPSS/PC (Statistical Package for the Science, ver 12.0. USA) 통계 프로그램을 이용하여 분석하 였다. 처리간의 평균비교는 t-test를 시행하였고 최소 유의성을 검정은 P-value 0.05로 평가하였 다.

\section{III. 결과 및 고찰}

\section{1. 옥수수 사일리지의 수분함량 및 $\mathrm{pH}$}

숙기별 옥수수 원형 곤포사일리지에 대한 수 분함량은 Fig. 1에서 보는 바와 같다. 사일리지 의 수분함량은 유숙기, 황숙기 및 완숙기로 수 확시기가 늦어짐에 따라 현저하게 감소하였다 $(\mathrm{P}<0.05)$. 그리고 유산균의 첨가 유무에 관계없 이 수분함량은 거의 영향을 받지 않았다.

옥수수 원형 곤포사일리지의 $\mathrm{pH}$ 는 Table 2, 4 및 6에서 보는 바와 같이 $\mathrm{pH}$ 는 유숙기, 황숙 기 및 완숙기가 각각 $3.75,3.66$ 및 3.64 로 안정 된 값을 보였다. 옥수수 트렌치 사일리지의 $\mathrm{pH}$ 는 유숙기, 황숙기 및 완숙기가 각각 $3.44,3.67$

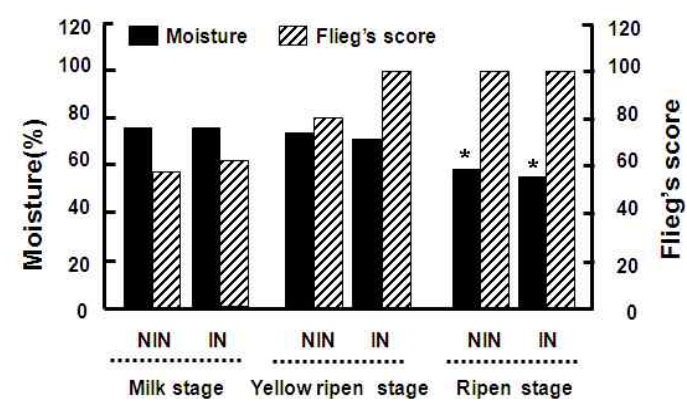

Fig. 1. Moisture content and Flieg's score of roll baled corn silage according to harvest stage of corn and inoculant. NIN: Non-inoculation of inoculant, IN: Inoculation of inoculant. * vs Milk stage $(\mathrm{P}<0.05)$. 
및 3.68로 옥수수 원형 곤포사일리지와 같이 안정된 값을 보였다. 그리고 유산균의 산생성 능력을 나타내는 $\mathrm{pH}$ 는 옥수수는 유산균의 첨 가유무에 상관없이 $\mathrm{pH}$ 는 안정된 상태를 유지 하였다. 유숙기의 옥수수 트렌치 사일리지의 $\mathrm{pH}$ 는 원형 곤포사일리지의 보다 감소되었으나 황숙기와 완숙기에서는 비슷한 경향을 보였다.

많은 연구자들은 사일리지 제조시 수분 함량 을 조절하기 위해서 예건을 실시하여 사일리지 의 품질과 $\mathrm{pH}$ 의 연관성을 조사하였는데 (송 등, 2009 ; 김 등, 2006b), 김 등 (1996)과 임 등 (2009)은 예건에 의해서 $\mathrm{pH}$ 가 감소한다고 하였 고, Manyawu 등 (2003)과 김 등 (2006b)은 예건 이 $\mathrm{pH}$ 를 증가시켰다고 하면서 상반된 보고를 하였다. 그러나 김 등 (2010)은 사일리지의 $\mathrm{pH}$
변화는 사료작물의 초종과 사일리지 제조시 건 물함량에 따라 $\mathrm{pH}$ 의 증감이 달라질 수 있다고 하였는데, 본 연구에서는 숙기가 다르고 수분 함량이 차이가 심하게 나타났음에도 불구하고 $\mathrm{pH}$ 의 변화는 거의 관찰되지 않았다. 이처럼 사 료작물의 초종이나 특히, 수분함량에 따라서 $\mathrm{pH}$ 차이의 변화가 예상되기 때문에 옥수수 원 형 곤포사일리지 제조시 수분 함량을 고려한 수확시기를 결정해야 할 것으로 사료된다.

\section{2. 옥수수 원형 곤포사일리지의 화학성분}

옥수수 원형 곤포사일리지 제조 후 60 일에 개봉한 옥수수의 화학성분은 Table 1 , Table 3 및 Table 5에서 보는 바와 같다. 옥수수 원형

Table 1. Effect of harvest of milk stage of corn and inoculant treatment on nutritive values of roll baled corn silage

\begin{tabular}{|c|c|c|c|c|c|c|c|}
\hline $\mathrm{SMM}^{1)}$ & Inoculant & Year & $\begin{array}{l}\mathrm{CP}^{6)} \\
(\%)\end{array}$ & $\begin{array}{c}\mathrm{ADF}^{7)} \\
(\%)\end{array}$ & $\begin{array}{c}\mathrm{NDF}^{8)} \\
(\%)\end{array}$ & $\begin{array}{c}\mathrm{TDN}^{9)} \\
(\%)\end{array}$ & $\begin{array}{c}\text { IVDMD }^{10)} \\
(\%)\end{array}$ \\
\hline \multirow{6}{*}{ Bale $^{2)}$} & \multirow{3}{*}{$\mathrm{NTR}^{4)}$} & 2009 & 9.89 & 33.49 & 53.10 & 67.09 & 62.8 \\
\hline & & 2010 & 8.11 & 30.44 & 49.15 & 68.38 & 67.6 \\
\hline & & Mean & 9.00 & 31.96 & 51.12 & 67.74 & 65.2 \\
\hline & \multirow{3}{*}{$\mathrm{TR}^{5)}$} & 2009 & 9.68 & 33.86 & 57.67 & 66.93 & 68.8 \\
\hline & & 2010 & 7.84 & 29.71 & 48.70 & 68.69 & 69.9 \\
\hline & & Mean & 8.76 & 31.79 & 53.18 & 67.81 & 69.3 \\
\hline \multirow{6}{*}{$\mathrm{TS}^{3)}$} & \multirow{3}{*}{ NTR } & 2009 & 9.33 & 29.02 & 47.09 & 68.99 & 62.7 \\
\hline & & 2010 & 7.84 & 28.47 & 45.12 & 69.22 & 73.2 \\
\hline & & Mean & 8.58 & 28.75 & 46.10 & 69.10 & 67.9 \\
\hline & \multirow{3}{*}{ TR } & 2009 & 9.75 & 29.28 & 48.46 & 68.88 & 66.4 \\
\hline & & 2010 & 7.92 & 28.41 & 45.28 & 69.25 & 71.9 \\
\hline & & Mean & 8.83 & 28.84 & 46.87 & 69.06 & 69.1 \\
\hline & \multicolumn{7}{|c|}{ Main-effect } \\
\hline \multicolumn{3}{|c|}{ Bale } & 8.88 & $31.88 \mathrm{a}$ & $52.15 \mathrm{a}$ & 67.77 & 67.2 \\
\hline \multicolumn{3}{|c|}{ TS } & 8.71 & $28.79 b$ & $46.49 \mathrm{~b}$ & 69.09 & 68.5 \\
\hline \multicolumn{8}{|c|}{ Sub-effect } \\
\hline \multicolumn{3}{|c|}{ NTR } & 8.79 & 30.35 & 48.61 & 68.42 & 66.5 \\
\hline \multicolumn{3}{|c|}{ TR } & 8.80 & 30.31 & 50.03 & 68.44 & 69.2 \\
\hline
\end{tabular}

1) SMM: Silage making method, ${ }^{2)}$ Bale: Round bale, ${ }^{3)}$ TS: Trench silo, ${ }^{4)}$ NTR: Non-treatment, ${ }^{5)}$ Treatment, ${ }^{6}$ CP: Crude protein, ${ }^{7)} \mathrm{ADF}$ : Acid detergent fiber, ${ }^{8)} \mathrm{NDF}$ : Neutral detergent fiber, ${ }^{9)}$ TDN: Total digestible nutrient, ${ }^{10)}$ IVDMD: in vitro dry matter digestibility.

$\mathrm{a}$ and $\mathrm{b}$ : Means with different letters within a column are significantly different at the $5 \%$ level 
Table 2. Effect of harvest of milk stage of corn and inoculant treatment on acidity and content of lactic acid in roll baled corn silage

\begin{tabular}{|c|c|c|c|c|c|c|}
\hline $\mathrm{SMM}^{1)}$ & Inoculant & Year & $\mathrm{pH}$ & $\begin{array}{c}\text { Lactate } \\
(\% / \mathrm{DM}) \\
\end{array}$ & $\begin{array}{c}\text { Acetate } \\
(\% / \mathrm{DM}) \\
\end{array}$ & $\begin{array}{l}\text { Butyrate } \\
(\% / \mathrm{DM}) \\
\end{array}$ \\
\hline \multirow{6}{*}{ Bale $^{2)}$} & \multirow{3}{*}{$\mathrm{NTR}^{4)}$} & 2009 & 3.76 & 2.25 & 6.78 & 0.00 \\
\hline & & 2010 & 3.76 & 4.87 & 5.13 & 0.00 \\
\hline & & Mean & 3.76 & 3.51 & 5.97 & 0.00 \\
\hline & \multirow{3}{*}{$\mathrm{TR}^{5)}$} & 2009 & 3.67 & 2.45 & 5.44 & 0.00 \\
\hline & & 2010 & 3.77 & 5.33 & 4.36 & 0.00 \\
\hline & & Mean & 3.72 & 3.88 & 4.91 & 0.00 \\
\hline \multirow{6}{*}{$\mathrm{TS}^{3)}$} & \multirow{3}{*}{ NTR } & 2009 & 3.22 & 9.29 & 1.38 & 0.00 \\
\hline & & 2010 & 3.55 & 7.72 & 1.65 & 0.00 \\
\hline & & Mean & 3.39 & 8.53 & 1.52 & 0.00 \\
\hline & \multirow{3}{*}{$\mathrm{TR}$} & 2009 & 3.22 & 9.95 & 1.48 & 0.00 \\
\hline & & 2010 & 3.54 & 8.09 & 1.48 & 0.02 \\
\hline & & Mean & 3.38 & 9.04 & 1.48 & 0.00 \\
\hline \multicolumn{7}{|c|}{ Main-effect } \\
\hline \multicolumn{3}{|c|}{ Bale } & $3.75 \mathrm{a}$ & $3.69 \mathrm{~b}$ & $5.44 \mathrm{a}$ & 0.00 \\
\hline \multicolumn{3}{|c|}{ TS } & $3.44 \mathrm{~b}$ & $8.78 \mathrm{a}$ & $1.50 \mathrm{~b}$ & 0.00 \\
\hline \multicolumn{7}{|c|}{ Sub-effect } \\
\hline \multicolumn{3}{|c|}{ NTR } & 3.62 & 6.02 & 3.75 & 0.00 \\
\hline \multicolumn{3}{|c|}{ TR } & 3.61 & 6.46 & 3.20 & 0.00 \\
\hline
\end{tabular}

${ }^{1)}$ SMM: Silage making method, ${ }^{2)}$ Bale: Round bale, ${ }^{3)}$ TS: Trench silo, ${ }^{4)}$ NTR: Non-treatment, ${ }^{5)}$ Treatment a and b: Means with different letters within a column are significantly different at the $5 \%$ level.

곤포사일리지는 수확시기가 늦어짐에 따라 조 단백질 함량은 감소하는 경향을 보였으나 섬유 소인 $\mathrm{ADF}$ 함량은 증가하였다. 그리고 유산균 의 첨가유무에 상관없이 비슷한 함량을 보였 다. 옥수수 트렌치 사일리지는 숙기가 진행됨 에 따라 $\mathrm{NDF}$ 와 $\mathrm{ADF}$ 함량은 증가하였으나 조 단백질 함량은 감소하였다. 유숙기 옥수수 트 렌치 사일리지의 $\mathrm{NDF}$ 와 $\mathrm{ADF}$ 함량은 원형 곤 포사일리지보다 감소되었으나 $(\mathrm{P}<0.05)$ 숙기별 조단백질과 TDN 함량은 사일리지 제조방법에 따라 차이를 보이지 않았다.

많은 연구자의 보고에 의하면 대부분의 사료 작물은 숙기가 진행됨에 따라 $\mathrm{NDF}$ 와 $\mathrm{ADF}$ 함 량은 증가하고 조단백질 함량은 감소 (김 등, 2010; 송 등, 2009; 김 등, 1996) 한다고 하였는 데 본 시험과 비슷한 경향을 보였다. 그리고 옥수수 원형 곤포사일리지 제조시 유산균의 첨 가는 사료가치에 영향을 주지는 않았지만 사
일리지의 품질에는 관여하므로 원형 곤포 제조 시 유산균의 첨가는 아주 중요한 것으로 사료 된다.

\section{3. 옥수수 원형 곤포사일리지의 소화율}

옥수수 원형 곤포 및 트렌치 사일리지의 in vitro 건물소화율은 Table 1, Table 3 및 Table 5 에서 보는 바와 같다. 옥수수 원형사일리지의 in vitro 건물소화율은 유숙기, 황숙기 및 완숙 기가 각각 67,69 및 $76 \%$ 였으며 트렌치 사일 리지의 in vitro 건물소화율도 각각 68, 72 및 $77 \%$ 를 보였다. 유숙기와 황숙기 옥수수 트렌치 사일리지의 in vitro 건물소화율은 원형 곤포사 일리지와 비슷하였고 유산균의 첨가유무에 상 관없이 사일리지의 in vitro 건물소화율은 비슷 한 수준을 보였다.

많은 연구결과에서 유산균 첨가제가 건물 소 
Table 3. Effect of harvest of yellow ripen stage of corn and inoculant treatment on nutritive values of roll baled corn silage

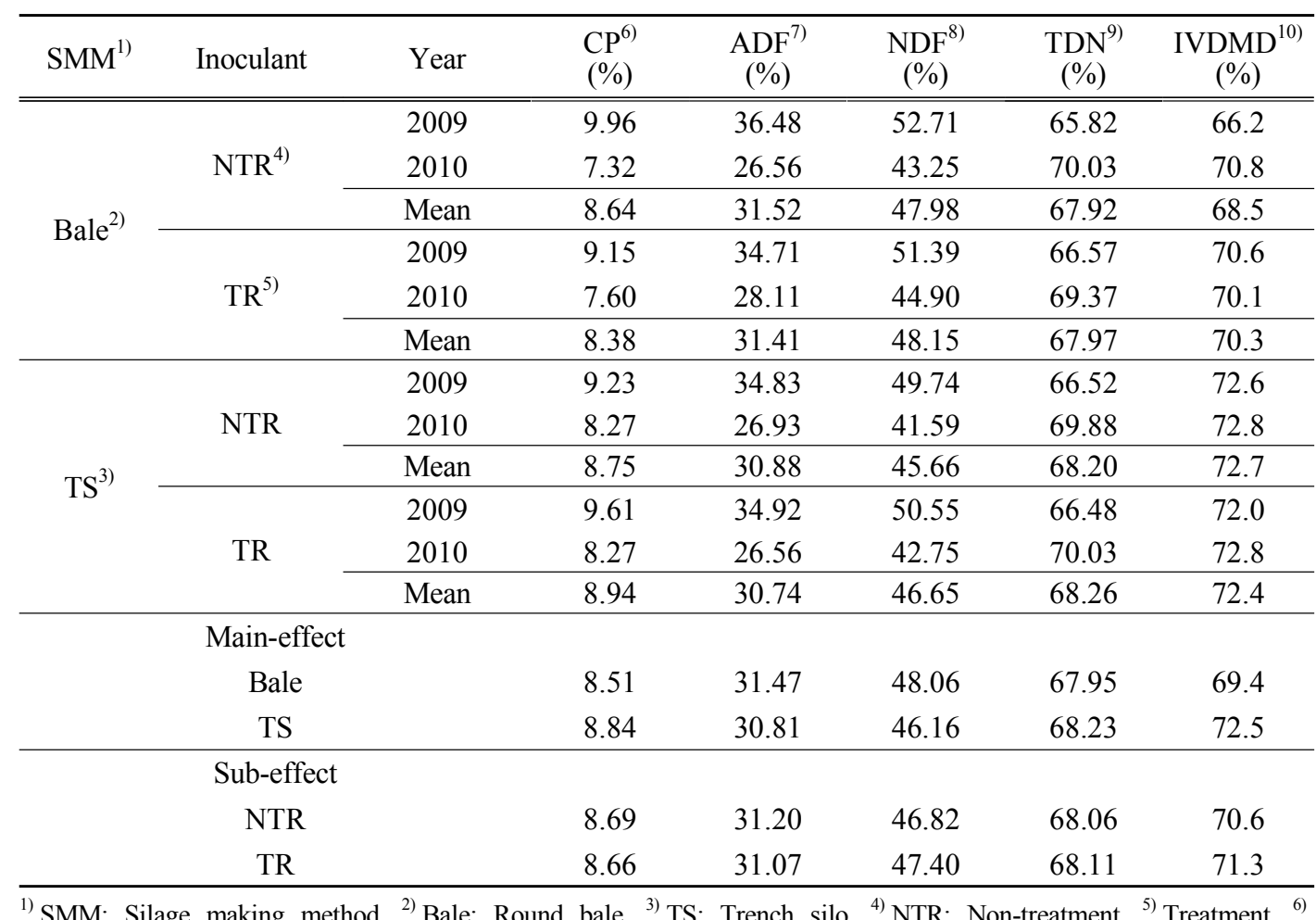

${ }^{1)}$ SMM: Silage making method, ${ }^{2)}$ Bale: Round bale, ${ }^{3)}$ TS: Trench silo, ${ }^{4)}$ NTR: Non-treatment, ${ }^{5)}$ Treatment, ${ }^{\text {) }}$ CP: Crude protein, ${ }^{7)} \mathrm{ADF}$ : Acid detergent fiber, ${ }^{8)} \mathrm{NDF}$ : Neutral detergent fiber, ${ }^{9)} \mathrm{TDN}$ : Total digestible nutrient, ${ }^{10)}$ IVDMD: in vitro dry matter digestibility.

화율 증가와 관련성이 있는 것으로 보고 (Patterson 등, 1997; Keady와 Steen, 1994)와 반대로 소화율 개선효과가 없는 것으로 보고 (Smith 등, 1993; Steen 등, 1989)로 대별되는데, 본 연 구에서는 옥수수 사일리지의 in vitro 건물소화 율이 개선되는 효과를 보이지 않았다. 그러나 Hristov 및 McAllister (2002)는 보리 사일리지에 미생물 첨가제를 처리함으로써 in situ 건물 소 화율에 영향을 주지는 않았지만 젖산균의 함량 과 개봉 후 호기적 안정성을 개선하는 데는 효 과가 있었다고 보고하였는데, 본 연구에서도 유사한 경향의 결과를 보여주었다. in vitro 건 물소화율은 초종과 제조시 건물함량에 따라 약 간의 변화는 관찰될 수 있겠으나 옥수수 원형 곤포사일리지의 경우에는 수확시기와 수분함량 에 상관없이 높은 소화율을 유지하기 때문에
사료가치가 우수하고 농가작업이 용이한 시기 에 예취하여 원형 곤포사일리지를 조제하는 것 이 경제적이나 가급적 황숙기에 원형 곤포사일 리지를 제조 하는 것이 유리할 것으로 생각된 다.

4. 옥수수 원형 곤포사일리지의 유기산 함량 과 품질등급

숙기별 옥수수 원형 곤포사일리지의 유기산 함량은 Table 2, Table 4 및 Table 6에서 보는 바와 같다. 옥수수 원형 곤포사일리지의 수확 시기가 늦어짐에 따라 젖산 함량은 증가하였으 나 초산 함량은 감소하였다. 그리고 낙산함량 은 유숙기 완숙기까지 거의 나타나지 않았다. 유숙기 옥수수 트렌치 사일리지의 젓산 함량은 
Table 4. Effect of harvest of yellow ripen stage of corn and inoculant treatment on acidity and content of lactic acid in roll baled corn silage

\begin{tabular}{|c|c|c|c|c|c|c|}
\hline $\mathrm{SMM}^{1)}$ & Inoculant & Year & $\mathrm{pH}$ & $\begin{array}{c}\text { Lactate } \\
(\% / \mathrm{DM}) \\
\end{array}$ & $\begin{array}{c}\text { Acetate } \\
(\% / \mathrm{DM}) \\
\end{array}$ & $\begin{array}{l}\text { Butyrate } \\
(\% / \mathrm{DM}) \\
\end{array}$ \\
\hline \multirow{6}{*}{ Bale $^{2)}$} & \multirow{3}{*}{$\mathrm{NTR}^{4)}$} & 2009 & 3.75 & 6.69 & 4.46 & 0.00 \\
\hline & & 2010 & 3.62 & 6.95 & 2.19 & 0.00 \\
\hline & & Mean & 3.69 & 6.80 & 3.35 & 0.00 \\
\hline & \multirow{3}{*}{$\mathrm{TR}^{5)}$} & 2009 & 3.73 & 5.87 & 4.37 & 0.00 \\
\hline & & 2010 & 3.67 & 5.90 & 2.08 & 0.00 \\
\hline & & Mean & 3.70 & 5.87 & 3.21 & 0.00 \\
\hline \multirow{6}{*}{$\mathrm{TS}^{3)}$} & \multirow{3}{*}{ NTR } & 2009 & 3.82 & 7.78 & 1.03 & 0.00 \\
\hline & & 2010 & 3.63 & 7.16 & 1.19 & 0.00 \\
\hline & & Mean & 3.72 & 7.49 & 1.11 & 0.00 \\
\hline & \multirow{3}{*}{$\mathrm{TR}$} & 2009 & 3.74 & 6.27 & 0.81 & 0.00 \\
\hline & & 2010 & 3.61 & 5.71 & 0.81 & 0.00 \\
\hline & & Mean & 3.67 & 5.97 & 0.81 & 0.00 \\
\hline \multicolumn{7}{|c|}{ Main-effect } \\
\hline & Bale & & 3.66 & 6.34 & $3.28 \mathrm{a}$ & 0.00 \\
\hline & TS & & 3.67 & 6.73 & $0.96 \mathrm{~b}$ & 0.00 \\
\hline \multicolumn{7}{|c|}{ Sub-effect } \\
\hline & NTR & & 3.67 & 7.15 & 2.23 & 0.00 \\
\hline & TR & & 3.67 & 5.92 & 2.01 & 0.00 \\
\hline
\end{tabular}

${ }^{1)}$ SMM: Silage making method, ${ }^{2)}$ Bale: Round bale, ${ }^{3)}$ TS: Trench silo, ${ }^{4)}$ NTR: Non-treatment, ${ }^{5)}$ Treatment $\mathrm{a}$ and $\mathrm{b}$ : Means with different letters within a column are significantly different at the $5 \%$ level.

Table 5. Effect of harvest of ripen stage of corn and inoculant treatment on nutritive values of roll baled corn silage

\begin{tabular}{|c|c|c|c|c|c|c|c|}
\hline $\mathrm{SMM}^{1)}$ & Inoculant & Year & $\begin{array}{l}\left.\mathrm{CP}^{6}\right) \\
(\%)\end{array}$ & $\begin{array}{c}\mathrm{ADF}^{7)} \\
(\%)\end{array}$ & $\begin{array}{c}\mathrm{NDF}^{8)} \\
(\%)\end{array}$ & $\begin{array}{c}\mathrm{TDN}^{9)} \\
(\%)\end{array}$ & $\begin{array}{c}\text { IVDMD }^{10)} \\
(\%)\end{array}$ \\
\hline \multirow{6}{*}{ Bale $^{2)}$} & \multirow{3}{*}{$\mathrm{NTR}^{4)}$} & 2009 & 7.99 & 38.98 & 52.97 & 64.76 & 78.3 \\
\hline & & 2010 & 7.46 & 37.41 & 41.01 & 69.67 & - \\
\hline & & Mean & 7.72 & 38.20 & 46.91 & 67.21 & 78.3 \\
\hline & \multirow{3}{*}{$\mathrm{TR}^{5)}$} & 2009 & 7.86 & 37.08 & 49.12 & 65.56 & 74.0 \\
\hline & & 2010 & 7.85 & 30.23 & 45.23 & 68.47 & - \\
\hline & & Mean & 7.85 & 33.65 & 47.17 & 67.02 & 74.0 \\
\hline \multirow{6}{*}{$\mathrm{TS}^{3)}$} & \multirow{3}{*}{ NTR } & 2009 & 8.32 & 38.41 & 51.99 & 65.00 & 76.7 \\
\hline & & 2010 & 7.72 & 30.96 & 46.98 & 68.16 & - \\
\hline & & Mean & 8.02 & 34.68 & 49.48 & 66.58 & 76.7 \\
\hline & \multirow{3}{*}{ TR } & 2009 & 8.29 & 40.33 & 54.88 & 64.18 & 77.4 \\
\hline & & 2010 & 7.69 & 38.91 & 43.48 & 69.04 & - \\
\hline & & Mean & 7.99 & 39.62 & 49.18 & 66.61 & 77.4 \\
\hline \multicolumn{8}{|c|}{ Main-effect } \\
\hline \multicolumn{3}{|c|}{ Bale } & 7.79 & 35.92 & 47.04 & 67.12 & 76.1 \\
\hline \multicolumn{3}{|c|}{ TS } & 8.00 & 34.65 & 49.33 & 66.20 & 77.5 \\
\hline \multicolumn{8}{|c|}{ Sub-effect } \\
\hline \multicolumn{3}{|c|}{ NTR } & 7.87 & 33.94 & 48.20 & 66.90 & 77.5 \\
\hline \multicolumn{3}{|c|}{ TR } & 7.92 & 36.63 & 48.18 & 66.81 & 75.7 \\
\hline
\end{tabular}


Table 6. Effect of harvest of ripen stage of corn and inoculant treatment on the acidity and content of lactic acid in roll baled corn silage

\begin{tabular}{|c|c|c|c|c|c|c|}
\hline $\mathrm{SMM}^{1)}$ & Inoculant & Year & $\mathrm{pH}$ & $\begin{array}{c}\text { Lactate } \\
(\% / \mathrm{DM})\end{array}$ & $\begin{array}{c}\text { Acetate } \\
(\% / \mathrm{DM})\end{array}$ & $\begin{array}{l}\text { Butyrate } \\
\text { (\%/DM) }\end{array}$ \\
\hline \multirow{6}{*}{ Bale $^{2)}$} & \multirow{3}{*}{$\mathrm{NTR}^{4)}$} & 2009 & 3.75 & 4.88 & 1.07 & 0.05 \\
\hline & & 2010 & 3.59 & 5.62 & 0.85 & 0.00 \\
\hline & & Mean & 3.67 & 5.25 & 0.95 & 0.05 \\
\hline & \multirow{3}{*}{$\mathrm{TR}^{5)}$} & 2009 & 3.57 & 4.39 & 0.79 & 0.02 \\
\hline & & 2010 & 3.64 & 4.98 & 1.19 & 0.02 \\
\hline & & Mean & 3.61 & 4.68 & 0.99 & 0.02 \\
\hline \multirow{6}{*}{$\mathrm{TS}^{3)}$} & \multirow{3}{*}{ NTR } & 2009 & 3.43 & 6.45 & 1.30 & 0.02 \\
\hline & & 2010 & 3.66 & 4.03 & 0.37 & 0.00 \\
\hline & & Mean & 3.55 & 5.26 & 0.83 & 0.01 \\
\hline & \multirow{3}{*}{$\mathrm{TR}$} & 2009 & 3.96 & 4.97 & 1.08 & 0.01 \\
\hline & & 2010 & 3.66 & 4.77 & 0.41 & 0.00 \\
\hline & & Mean & 3.81 & 4.87 & 0.74 & 0.00 \\
\hline \multicolumn{7}{|c|}{ Main-effect } \\
\hline \multicolumn{3}{|c|}{ Bale } & 3.64 & 4.97 & 0.97 & 0.03 \\
\hline \multicolumn{3}{|c|}{$\mathrm{TS}$} & 3.68 & 5.06 & 0.79 & 0.01 \\
\hline \multicolumn{7}{|c|}{ Sub-effect } \\
\hline \multicolumn{3}{|c|}{ NTR } & 3.61 & 5.26 & 0.89 & 0.03 \\
\hline \multicolumn{3}{|c|}{ TR } & 3.71 & 4.78 & 0.83 & 0.01 \\
\hline
\end{tabular}

${ }^{1)}$ SMM: Silage making method, ${ }^{2)}$ Bale: Round bale, ${ }^{3)}$ TS: Trench silo, ${ }^{4)}$ NTR: Non-treatment, ${ }^{5)}$ Treatment

원형 곤포사일리지보다 증가하였으나 $(\mathrm{P}<0.05)$ 황숙기와 완숙기의 젖산 함량은 원형 곤포사일 리지와 비슷하였다. 그리고 유숙기와 황숙기의 초산 함량은 원형 곤포사일리지에서 증가되었 다 $(\mathrm{P}<0.05)$. 완숙기에서는 제조방법에 따라 젖 산과 초산 함량은 큰 차이를 보이지 않았다.

Pitt (1990)는 사일리지의 총유기산 중 젖산함 량은 사일리지의 $\mathrm{pH}$ 와 당 함량과 상관관계가 높으며, 사일리지의 $\mathrm{pH}$ 가 낮고, 식물체의 당 함량이 많을수록 총유기산 중 젖산 함량이 증 가한다고 하였으며, 양질의 사일리지는 젖산함 량이 적어도 $70 \%$ 이상이어야 한다고 하였다. 일반적으로 옥수수는 당 함량이 사일리지를 제 조하는데 적당하여 숙기별 사일리지 품질에는 크게 영향을 주지 않을 것으로 생각된다(김 등, 2008).
Flieg 법에 의한 사일리지 품질등급은 각 산 (초산, 낙산 및 젖산)의 비율로서 score를 표시 하게 되는데 수확시기별 점수를 보면 유숙기는 60점 (양호), 황숙기는 90점 (우수), 완숙기는 100점 (우수)으로 나타났다 (Fig. 1).

이상의 Flieg 법의 결과에서 보는 바와 같이 사일리지 조제시 사일리지 발효에 필요한 수분 이 너무 많거나 적으면 양질의 발효가 제한적 으로 일어나는 것으로 알려져 있지만 옥수수 원형 곤포사일리지 제조시에는 수분함량이 많 을 때에 문제가 있는 것으로 보여진다.

이상의 결과를 요약해 볼 때 완숙기가 우수 한 등급으로 나타났지만 완숙기에는 원형 곤포 사일리지 제조시 기계작업으로 인해 옥수수 낱 알의 손실이 많이 일어나므로 사일리지 조제시 기를 황숙기로 맞추는 것이 유리할 것이다. 
따라서 옥수수 원형 곤포사일리지의 제조는 황숙기가 적기로 판단되지만 농가의 여건에 따 라 황숙기 전후에도 원형 곤포사일리지가 가능 한 것으로 생각된다. 그러나 양질의 원형 곤포 사일리지를 제조하고자 할 때에는 반드시 황숙 기에 조제하는 것이 유숙기나 완숙기에 비해 품질이 우수할 것으로 생각되며 유산균의 첨가 는 사일리지의 품질을 향상시키는 좋은 방법으 로 평가된다.

\section{IV. 요 약}

본 시험은 수확시기가 옥수수 원형 곤포사일 리지의 품질에 미치는 영향을 구명하기 위하여 2009년부터 2010년까지 국립축산과학원에서 수 행되었다. 옥수수 사일리지 전용 품종인 광평 옥을 이용하여 숙기별 3회 (유숙기, 황숙기 및 완숙기)에 걸쳐 수확을 하여 사일리지로 조제 하였다. 숙기가 진행됨에 따라 옥수수 원형 곤 포사일리지의 조단백질과 $\mathrm{TDN}$ 함량은 감소하 는 경향을 보였으나 섬유소인 $\mathrm{NDF}$ 및 $\mathrm{ADF}$ 함 량은 증가하였다. 그리고 숙기별 in vitro 건물 소화율은 비슷하였다. 숙기별 사일리지의 $\mathrm{pH}$ 는 3.8 4.0을 유지하였으며, 숙기별 차이는 크지 않았다. 또한 생육이 진행됨에 따라 초산 함량 은 감소되었으나 젖산 함량은 증가되었다. 그 리고 품질등급은 완숙기 $>$ 황숙기 $>$ 유숙기 순 으로 나타났다. 이상의 결과를 종합하여 볼 때 양질의 옥수수 원형 곤포사일리지 제조를 위해 서는 황숙기에 수확하여 사일리지를 만드는 것 이 옥수수 사일리지 발효를 향상시킬 수 있다.

\section{$\mathrm{V}$. 인 용 문 헌}

1. 김정갑, 한민수, 김건엽, 한정대, 강우성, 신정남. 1995. 주요 사료작물의 곤포 Silage 조제이용에 관한 연구. II. 생육단계별 건물 축적 형태와 곤 포사일리지 조제이용. 한초지 15(3):157-230.

2. 김상록, 김곤식, 우제훈, 이준우, 성경일. 2004. 연천지역에 있어서 생볏짚 원형 곤포사일리지의
부위별 사료성분 및 발효품질. 한초지 24(3):253260.

3. 김원호, 이종경, 박형수, 황보순, 임영철, 지희정, 이효원, 윤봉기, 서 성. 2009. 논에서 생육특성 과 수량이 우수한 두과 사료작물 선발. 한초지 29(4):307-312.

4. 김원호, 신재순, 임영철, 서 성, 김기용, 이종경. 2005. 논에서 여름 및 겨울 사료작물의 최적 작 부체계에 관한 연구. 한초지 25(4):233-238.

5. 김종근, 정의수, 서 성, 함준상, 윤세형, 임영철. 2006a. 유산균제 첨가가 라운드베일 목초 사일리 지의 품질에 미치는 영향. 한초지 26(3):139-146.

6. 김종근, 정의수, 서 성, 강우성, 함준상, 김동암. 2001. 수확시 숙기가 호밀 라운드베일 사일리지 의 품질변화에 미치는 영향. 한초지 21(1):1-6.

7. 김종근, 정의수, 서 성, 함준상, 김맹중, 이종경. 2006b. 예건기간이 라운드베일 목초 사일리지의 품질에 미치는 영향. 한초지 26(1):39-44.

8. 김종근, 정의수, 서 성, 강우성, 함준상, 이성철. 2000a. 제조 방법이 라운드베일 연맥 사일리지의 품질에 미치는 영향. 한초지 20(3):185-192.

9. 김종근, 서 성, 정의수, 강우성, 함준상, 김동암. $2000 \mathrm{~b}$. 수확시 숙기가 호밀 라운드베일 사일리지 의 사료가치 변화에 미치는 영향. 한초지 20(4): 215-316.

10. 김종덕, 이현진, 전경협, 양가영, 권찬호, 성하균, 황보순, 조익환. 2010. 수확시기, 예건 및 싸라기 처리가 유기 청보리의 사초 생산성 및 사일리지 품질에 미치는 영향. 한초지 30(1):25-34.

11. 김종근, 정의수, 서 성, 김맹중, 이종경, 윤세형, 임영철, 조용민. 2008. 수확시기 및 품종이 총체 벼 사일리지의 품질에 미치는 영향. 한초지 28 (1):29-34.

12. 김정갑, 진현주, 신재순, 정의수, 한민수. 1996. 봄 재배 연맥의 silage 제조 이용시 예건 및 formic acid 처리에 의한 품질개선 효과. 한초지 16(2):155-160.

13. 농림수산식품부. 2010. 2010년 조사료대책 추진 관련 협의회 $\mathrm{p} 24$.

14. 서진교, 이정환. 2009. [쌀 산업정책연구 시리즈 13] 한시가 급한 쌀 조기관세화. 인스티튜트, 시 선집중 $\mathrm{GSnJ}, 72(1): 1-17$.

15. 성경일, 김곤식, 이준우, 김병완, 김상록. 2005. 연천지역에 있어서 옥수수 사일리지의 개봉 후 경과기간에 따른 사료성분 및 발효품질. 한초지 25(1):43-50. 
16. 송태화, 한옥규, 윤성근, 박태일, 김경훈, 김기종. 2009. 청보리의 수확시기별 예건시간에 따른 수 분과 사일리지 품질변화. 한국농개지 21(4):316321.

17. 송 진, 최윤희, 김정태, 이춘기, 손정록. 2007. 2006년 도입 밥쌀용 수입쌀 국내 유통 실태. 한 작지 52(별책1):141-141.

18. 신재순, 김원호, 윤세형, 임영철, 임근발, 서 성. 2008. 중부지역 논에서 월년생 두과 사료작물의 생육특성 및 수량 비교. 한초지 28(1):13-18.

19. 이정환. 2006. '05 쌀값대란 해부. 인스티튜트, 시선집중 $\mathrm{GSnJ}, 8: 1-17$.

20. 이정환, 김관수, 김명환, 김태균, 사공용, 안동환, 임정빈. 2006. 쌀 산업을 지배하는 원리 인스티 튜트, pp. 1-186.

21. 임현진, 김종덕, 이현진, 전경협, 양가영, 권찬호, 윤세형. 2009. 예건이 수수×수단그라스 교잡종 유기 사일리지의 품질에 미치는 영향. 한유농지 17(4):519-527.

22. 전영서. 2004. 농산물시장 개방화와 사회후생의 변화 - 쌀시장을 중심으로 -. 한국경제연구, 13 : 111-129.

23. 조익환. 2007. 유휴 논 토양에서 액상 우분뇨의 시용이 톨 페스큐의 건물수량과 사료가치에 미 치는 영향. 한초지 27(1):9-20.

24. 지희정, 김원호, 김기용, 이상훈, 윤세형, 임영철. 2009a. 논에서 배수조건에 따른 사일리지용 옥수 수 품종의 생육특성, 생산성 및 품질 비교. 한초 지 29(4):329-336.

25. 지희정, 이종경, 김기용, 윤세형, 임영철, 권오도, 이희봉. 2009b. 남부지방 논에서 사일리지용 옥 수수 품종의 생육특성, 생산성 및 품질 비교. 한 초지 29(1):13-18.

26. AOAC. 1990. Official method of analysis. 15thed. Washington, DC. 15th ed.

27. Bevre, L. 1988. Silage making in round bales. Buscap Og Avdratt. 40(2):100-103. Norway.

28. Jurgens, M.H. 1982. Animal feeding and nutrition. Kentall \& Hunt Publishing, Inc. Virginia.

29. Goering, H.K. and P.J. Van Soest. 1970. Forage fiber analysis. Agic. Handbook 379, U. S. Gov. Print. Office, Washington, DC.

30. Hristove, A.N. and T.A. McAllister. 2002. Effect of inoculants on whole-crop barley silage fermentation and dry matter disappearance in situ. J. Anim. Sci. 80:510-516.
31. Keady, T.W.J. and R.W.J. Steen. 1994. Effects of treating low dry matter grass with a bacterial inoculant on the intake and performance of beef cattle and studies on its mode of action. Grass Forage Sci. 49:438-446.

32. Manyawu, G.J., S. Sobanda, C. Mutisi, I.C. Chakoma and P.N. Ndiweni. 2003. Effect of prewilting and incorporation of maize meal on the fermentation of banagrass silage. Asian-Aust. J. Anim. Sci. 16(6):843-851.

33. Moore, J.E. 1970. Procedure for the two-stage in vitro digestion of forage. Univ. of Florida, Depart. of Anim. Sci.

34. Patterson, D.C., C.S. Mayne, F.J. Gordon and D.J. Kilpatrick. 1997. An evaluation of an inoculant/ enzyme preparation as an additive for grass silage for dairy cattle. Grass Forage Sci. 52:325-335.

35. Pitt, R.E. 1990. Silage and hay preservation. National, Agriculture and Engineering Service (NRAES). Cooperative Extension. Cornell University.

36. Romahn. W. 1988. Big bale haylage fits our operation. Moard's Adiryman. March 10. Hoard and sons company. Fort Akinson, Wisconsin. p. 255 .

37. Smith, E.J., A.R. Henderson, J.D. Oldham, D.A. Whitaker, K. Aitcheson, D. H. Anderson, and J. M. Kelly. 1993. The influence of an inoculant/ enzyme preparation as an additive for grass silage offered in combination with three levels of concentrate supplementation on performance of lactating dairy cows. Anim. Prod. 56:301-310.

38. Steen, R.E.J., E.F. Unsworth, H.I. Gracey, S.J. Kennedy, R. Anderson and D.J. Kilpatrick. 1989. Evaluation studies in the development of a commercial bacterial inoculant as an additive for grass silage. 3. Responses in growing cattle and interaction with protein supplementation. Grass Forage Sci. 44:381-390.

(접수일: 2011년 2월 9일, 수정일 1차: 2011년 2월 17일, 수정일 2차: 2011년 2월 22일, 게재확정일: 2011년 3월 28일) 